\title{
Perkecambahan Biji, Kandungan Pigmen Fotosintesis dan Pertumbuhan Tanaman Kacang Tunggak (Vigna unguiculata L. Walp.) pada Kondisi Naungan
}

\section{Seed Germination, Photosyntetic Pigment Content and Growth of Cowpea's Plant's (Vigna unguiculata L. Walp.) in Shading Treatment}

\author{
Nadya Aulia Azhari, Munifatul Izzati, Endang Saptiningsih* \\ Program Studi Biologi, Fakultas Sains dan Matematika, Universitas Diponegoro \\ *Email : saptiningsihe@gmail.com
}

Diterima 13 Agustus 2020 / Disetujui 1 Oktober 2020

\begin{abstract}
ABSTRAK
Kacang tunggak merupakan salah satu jenis kacang yang memiliki kandungan protein tertinggi kedua setelah kedelai. Pemanfaatan yang belum optimal menyebabkan kurangnya pengembangan intensif dalam produksi kacang tunggak, termasuk dalam budidayanya. Budidaya yang dilakukan secara tumpang sari dengan tanaman lainnya menyebabkan kacang tunggak ternaungi. Naungan pada tanaman dapat menyebabkan perubahan lingkungan mikro yang berdampak pada pertumbuhan tanaman. Tujuan penelitian ini untuk mengetahui pengaruh naungan terhadap perkecambahan benih, kandungan pigmen fotosintesis dan pertumbuhan kacang tunggak. Penelitian menggunakan Rancangan Acak Lengkap (RAL) dengan faktor tunggal berupa naungan. Perlakuan terdiri dari kontrol (tanpa naungan) dan perlakuan naungan (40\%). Masing-masing perlakuan dengan 3 ulangan. Parameter yang diamati berupa daya perkecambahan biji, tinggi batang, jumlah daun, waktu munculnya bunga pertama, jumlah polong, berat basah, berat kering, klorofil a, klorofil b, total klorofil dan karotenoid. Data dianalisis dengan uji T pada taraf signifikansi 5\%. Hasil penelitian menunjukkan bahwa perlakuan naungan tidak berpengaruh terhadap kandungan klorofil a, klorofil b, klorofil total dan karotenoid, namun menunjukkan perbedaan yang signifikan terhadap persentase perkecambahan, tinggi tanaman, jumlah daun, durasi kemunculan bunga pertama, jumlah polong, berat basah serta berat kering tanaman.
\end{abstract}

Kata kunci : kacang tunggak, naungan pigmen fotosintesis, menghindar, polong

\begin{abstract}
Cowpea was one type of bean which contents the second highest protein after soybeans. Non-optimal utilization caused the lack of intensive development in cowpea production, including in its cultivation. Cultivation which was done by intercropping with other plants caused the cowpea to be shaded. Shade in plants can cause changes in the microenvironment that have an impact on plant growth. The purpose of this research was to determine the effect of shade on the pigment composition and growth of cowpeas. The research used the Completely Randomized Design (CRD) with single factor in the form of shade. The treatment used the open control treatment and one layer of paranet shade treatment with 3 replications. The observed parameters were percentage of seed germination; stem height, number of leaves, first flower appearance time, number of pods, wet weight, dry weight, chlorophyll a, chlorophyll b, total chlorophyll and carotenoid, analyzed by $\mathrm{T}$ test at $95 \%$ confidence level, and in graphical form. The result showed that shading was not significantly differences in the content of chlorophyll a, chlorophyll b, total chlorophyll, and carotenoids, but showed significantly differences in the percentage of germination, height, number of leaves, duration of appearance of the first flower, number of pods, wet weight and dry weight of plants.
\end{abstract}

Keywords : cowpea, shade, photosynthetic pigments, avoid, pods 


\section{PENDAHULUAN}

Indonesia dengan kekayaan alam yang tinggi mempunyai aneka ragam tanaman yang tumbuh subur. Kacang-kacangan merupakan salah satu komoditas yang banyak ditemui di wilayah Indonesia. Kacang-kacangan memiliki kandungan protein antara $20-35 \%$, karbohidrat, lemak, vitamin, mineral dan serat yang baik untuk dikonsumsi. Salah satu jenis kacang yang banyak di konsumsi masyarakat Indonesia adalah kacang tunggak. Kacang tunggak memiliki kandungan yang tinggi sebesar $22,90 \%$, dan merupakan tertinggi kedua setelah kacang kedelai (Ismayanti dan Harijono, 2015). Kacang tunggak memiliki peluang dalam menggantikan kacang kedelai sebagai bahan baku industri. Namun pemanfaatan kacang tunggak di Indonesia masih terbilang sangat minimal, karena kacang tunggak belum mendapatkan prioritas untuk dikembangkan secara intensif.

Budidaya tanaman kacang tunggak di Indonesia banyak dilakukan dengan menggunakan sistem tumpang sari dengan tanaman lainnya. Tumpang sari tanaman kacang tunggak dengan tanaman lainnya menyebabkan tanaman kacang tunggak mendapatkan naungan secara alami. Naungan menyebabkan beberapa perubahan diantaranya adalah perubahan lingkungan mikro meliputi: intensitas cahaya, temperatur dan kelembaban udara (Kittas et al., 2009). Perubahan lingkungan mikro akan berdampak pada pertumbuhan dan produktivitas tanaman (Masabni et al., 2016).

Wartenberg et al. (2019), melaporkan bahwa naungan berpengaruh positif terhadap hasil panen kakao dan gliricidia namun tidak berpengaruh terhadap hasil panen rambutan dan durian. Pada tanaman tomat dan cabai komersial, naungan sebesar $50 \%$ dapat mengurangi cekaman fotokimia sehingga tidak berdampak terhadap berat segar dan berat kering tajuk serta hasil panen (Masabni et al., 2016). Pengaruh naungan juga dilaporkan meningkatkan specific leaf area (SLA) dan kandungan klorofil, namun menurunkan kapasitas fotosintesis dan rasio klorofil $\mathrm{a} / \mathrm{b}$ pada varietas kedelai yang toleran terhadap naungan. Sementara pada varietas yang menghindari naungan memperlihatkan peningkatan batang utama, pemanjangan hipokotil dan alokasi biomassa menuju batang (Gong et al., 2015). Tanaman kacang tunggak merupakan salah satu tanaman legum selain kedelai. Penelitian ini bertujuan untuk mengkaji pengaruh naungan terhadap perkecambahan benih, komposisi pigmen fotosintesis dan pertumbuhan kacang tunggak $(V$. unguiculata).

\section{METODE PENELITIAN}

\section{Bahan tanaman dan pelaksanaan penelitian}

Penelitian menggunakan benih tanaman kacang tunggak (Vigna unguiculata L. Walp.) varietas KT-6 yang diperoleh dari Balai Penelitian Tanaman Aneka Kacang dan Umbi di Malang. Penelitian dilaksanakan pada bulan September 2019 sampai dengan Desember 2019 di rumah kawat Laboratorium Biologi Fakultas Sains dan Matematika, Laboratorium Biologi Struktur dan Fungsi Tumbuhan Departemen Biologi dan Laboratorium Terpadu Universitas Diponegoro Semarang.

Penelitian ini dilakukan dengan cara benih disemai pada media tanam berupa campuran dari tanah, sekam abu dan pupuk kandang dengan perbandingan 1:1:1. Saat semai berumur satu minggu dipindahkan ke polybag ukuran $18 \times 18 \times 25$ $\mathrm{cm}$ yang berisi media tanam campuran tanah, sekam abu dan pupuk kandang dengan perbandingan 1:1:1. Perlakuan berupa naungan paranet $40 \%$ dan tanpa naungan (kontrol) diberikan saat penanaman semai hingga fase panen kacang tunggak. Perawatan tanaman meliputi penyiraman, penyiangan dan pemupukan.

Penelitian menggunakan Rancangan Acak Lengkap (RAL) satu faktor yaitu naungan dengan 3 ulangan. Data dianalisis menggunakan Uji $\mathrm{T}$ pada taraf signifikansi 5\% dan ditampilkan dalam bentuk grafik. Seluruh analisis data dilakukan dengan program IBM SPSS Statistics 22 dan Microsoft Excel 2016.

\section{Daya berkecambah}

Benih kacang tunggak sebanyak 10 benih per cawan diletakkan secara acak. Media untuk uji daya berkecambah menggunakan kapas yang telah 
dibasahi dengan air. Selanjutnya cawan diletakkan pada tempat yang ternaungi dan tidak ternaungi. Pengamatan dilakukan selama 7 hari pertama terhadap perkecambahan normal yang ditandai dengan tumbuhnya plumula dan radikula (Latue et al., 2019). Perkecambahan kemudian dihitung menggunakan rumus:

$\frac{\text { jumlah kecambah nomal }}{\text { jumlah benih yang ditebar }} \times 100 \%$

\section{Pengukuran kadar pigmen klorofil dan karotenoid}

Pengukuran kadar pigmen fotosintesis menggunakan daun yang telah masak secara fisiologis sebesar 0,1 g. Ekstraksi pigmen dilakukan dengan metode ekstraksi nitrogen cair dan aseton 100\%. Filtrat kemudian dianalisis menggunakan spektrofotometer Hitachi Double Beam UH5300 pada panjang gelombang $470 \mathrm{~nm}, 646 \mathrm{~nm}$, dan 663 nm. Kadar klorofil dihitung dengan rumus perhitungan Wellburn (1994).

\section{Pengukuran parameter pertumbuhan}

Parameter pertumbuhan yang diukur meliputi tinggi tanaman, jumlah daun, berat basah dan berat kering tanaman, waktu bunga pertama terbentuk serta jumlah polong. Pengukuran pertumbuhan vegetatif dilakukan pada fase vegetatif akhir, sedangkan pengukuran waktu bunga terbentuk pertama kali dilakukan di awal pertumbuhan generatif dan jumlah polong diukur saat panen.

\section{HASIL DAN PEMBAHASAN}

\section{Perkecambahan benih}

Berdasarkan pengamatan dan hasil uji $\mathrm{T}$ daya berkecambah benih kacang selama 7 hari, menunjukkan naungan berpengaruh nyata terhadap persentase benih yang berkecambah (Gambar 1). Persentase benih yang berkecambah pada naungan $40 \%$ lebih tinggi dibanding benih pada tempat kontrol.

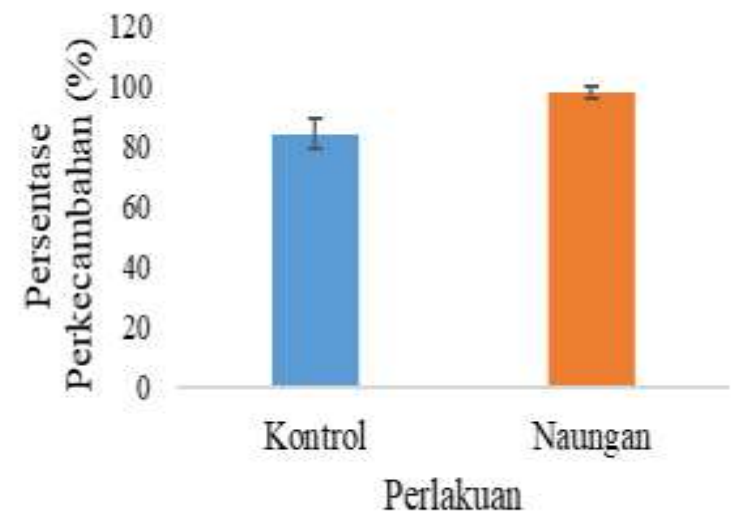

Gambar 1. Pengaruh naungan $40 \%$ terhadap perkecambahan benih. Nilai angka adalah mean \pm SE $(n=3)$.

Hasil penelitian pengaruh naungan terhadap daya perkecambahan benih kacang tunggak ini didukung oleh penelitian yang dilakukan Tabin dan Shrivastava (2014) pada Aquilaria malaccensis. Naungan menyebabkan peningkatan persentase perkecambahan biji Aquilaria malaccensis. da Silva et al. (2015), juga melaporkan bahwa naungan meningkatkan daya perkecambahan biji Physocalymma scaberrimum. Naungan mempengaruhi jumlah intensitas cahaya yang sampai di sekitar biji, selanjutnya akan berdampak pada lingkungan mikro di sekitar biji meliputi suhu, kelembaban dan kandungan air. Pada kondisi tanpa naungan akan terjadi intensitas cahaya dan suhu yang tinggi sehingga mengakibatkan penurunan kandungan air media, menghambat metabolisme perkecambahan serta mempercepat kerusakan biji (da Silva et al., 2015). Pemberian naungan pada benih kacang tunggak nampaknya menurunkan intensitas cahaya dan suhu di sekitar biji sehingga mempertahankan kandungan air di dalam media. Penyerapan air oleh biji kacang tunggak akan 
mengaktifkan sinyal hormonal dan berbagai enzim yang terkait dengan perkecambahan.

\section{Pigmen Klorofil, Karotenoid, Tinggi Tanaman dan Jumlah Daun}

Berdasarkan analisis pigmen fotosintesis, naungan $40 \%$ tidak berpengaruh nyata $(\mathrm{P}>0,05)$ terhadap rerata kadar klorofil a, klorofil $b$, klorofil total dan karotenoid (Gambar 2). Berbeda dengan penelitian Idris et al. (2018) pada daun tanaman Vernonia amygdalina, yang melaporkan bahwa perlakuan naungan meningkatkan jumlah klorofil a, klorofil b, klorofil total dan karotenoid. Penelitian Idris et al. (2019) pada Psidium guajava menyatakan bahwa intensitas cahaya yang rendah mengakibatkan kandungan klorofil a, klorofil b dan klorofil total tinggi, namun kandungan karotenoid tidak terpengaruh secara signifikan dalam kondisi intensitas cahaya yang maksimal. Nampaknya tanaman $V$. amygdalina dan $P$. guajava melakukan strategi toleransi terhadap kondisi naungan melalui peningkatan kandungan klorofil. Huang et al. (2011), menyatakan optimalisasi penyerapan cahaya oleh tanaman dalam kondisi naungan dilakukan dengan meningkatkan kandungan klorofil. Peningkatan kandungan klorofil akan mempengaruhi fungsi light-harvesting complex (LHC) sehingga berdampak terhadap kapasitas fotosintesis.

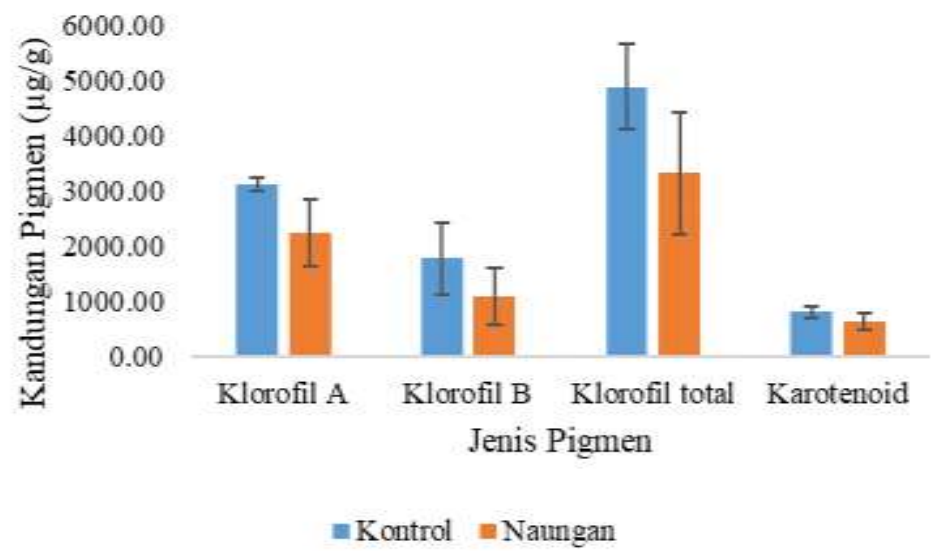

Gambar 2. Kandungan pigmen fotosintesis dalam kondisi naungan $40 \%$. Nilai angka adalah mean \pm SE ( $n=3)$.

Naungan tidak mempengaruhi kandungan pigmen fotosintesis pada kacang tunggak, namun terjadi pola peningkatan tinggi tanaman dan jumlah daun dibanding kontrol (tanpa naungan) dengan $(\mathrm{P}<0,05)$ (Gambar 3). Hal ini menunjukkan bahwa optimalisasi penyerapan cahaya pada kacang tunggak yang ternaungi dilakukan dengan peningkatan tinggi tanaman dan jumlah daun. Gommers et al. (2013) dan Roig-Villanova \& Martinez-Garcia (2016), melaporkan bahwa strategi avoid pada tanaman saat ternaungi dilakukan dengan pemanjangan batang dan petiola serta peningkatan SLA. Strategi avoid ini didukung oleh aktivitas beberapa hormon yaitu auksin, giberelin, brassinosteroid, etilen serta fitokrom. Nampaknya respon kacang tunggak terhadap naungan dilakukan dengan strategi avoid untuk mengoptimalkan penyerapan cahaya. Beberapa tanaman hortikultura antara lain kacang kedelai (Chairudin et al., 2015) dan bawang sabrang (Yusuf, 2009) menunjukkan pola yang sama yaitu peningkatan tinggi tanaman dalam kondisi ternaungi.

Tanaman memasuki fase reproduktif setelah fase vegetatif berakhir. Secara umum naungan mempengaruhi tanaman meliputi: pemanjangan batang dan daun, membatasi percabangan, meningkatkan SLA dan menurunkan alokasi biomassa ke akar (Semchenko et al., 2012). Kualitas dan kuantitas variabel-variabel pertumbuhan selama fase vegetatif akan menentukan variabel-variabel pertumbuhan pada fase reproduktif. Hasil analisis uji T menunjukkan adanya perbedaan yang signifikan $(\mathrm{P}<0,05)$ terhadap durasi kemunculan bunga pertama dan jumlah polong (Gambar 4). Naungan paranet sebesar $40 \%$ memperpanjang durasi kemunculan 
bunga pertama dan menurunkan jumlah polong pada tanaman kacang tunggak (Gambar 4). Pada penelitian ini terlihat bahwa naungan menurunkan biomassa tanaman meliputi tajuk, akar dan total tanaman (Gambar 5). Hal ini membuktikan bahwa naungan membatasi jumlah energi cahaya yang masuk dan diserap oleh tanaman sehingga mempengaruhi kapasitas fotosintesis dan pertumbuhan tanaman. Penurunan pertumbuhan tanaman selama fase vegetatif akan menurunkan pertumbuhan reproduktif dan produktivitas tanaman. Pada Plukenetia volubilis dilaporkan bahwa naungan sebesar 20-52\% mengurangi potensi inisiasi pembungaan, pembentukan bunga dan buah (Cai, 2011). Pada tanaman Petunia
(Petunia $x$ hybrida), naungan 50\% menyebabkan penundaan waktu berbunga, penurunan jumlah bunga serta warna bunga yang berubah. Selain itu, jika $10 \%$ naungan ditambahkan akan menyebabkan terjadinya keterlambatan pembungaan Petunia selama 2 hari (Prasundari dkk., 2018). Intensitas cahaya tinggi yang diterima daun akan mempercepat produksi hormon pembungaan dan mengirim sinyal untuk mengubah tunas vegetatif menjadi tunas reproduktif (Astuti dan Darmanti, 2010). Pada tanaman kacang tunggak, durasi munculnya bunga pertama pada perlakuan tanpa naungan (kontrol) lebih pendek dibanding perlakuan naungan.
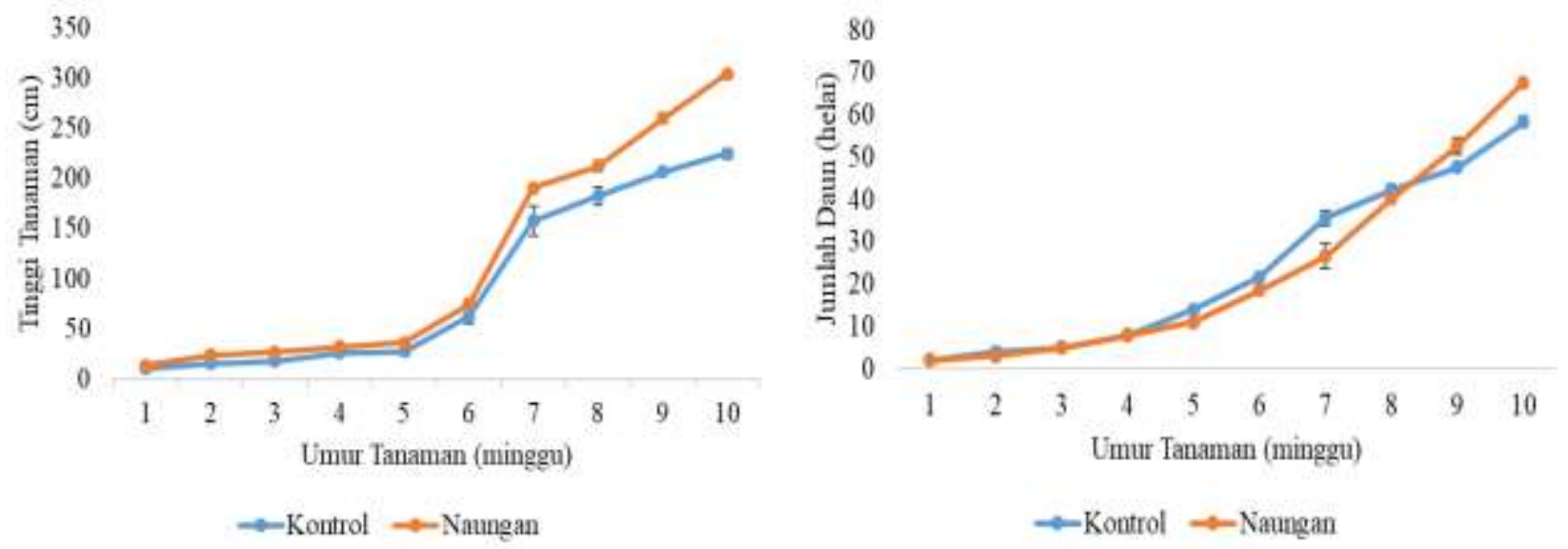

Gambar 3. Tinggi tanaman dan jumlah daun dalam naungan $40 \%$ selama 10 minggu. Nilai angka adalah mean $\pm \operatorname{SE}(n=3)$

\section{Kemunculan Bunga Pertama dan Jumlah Polong}
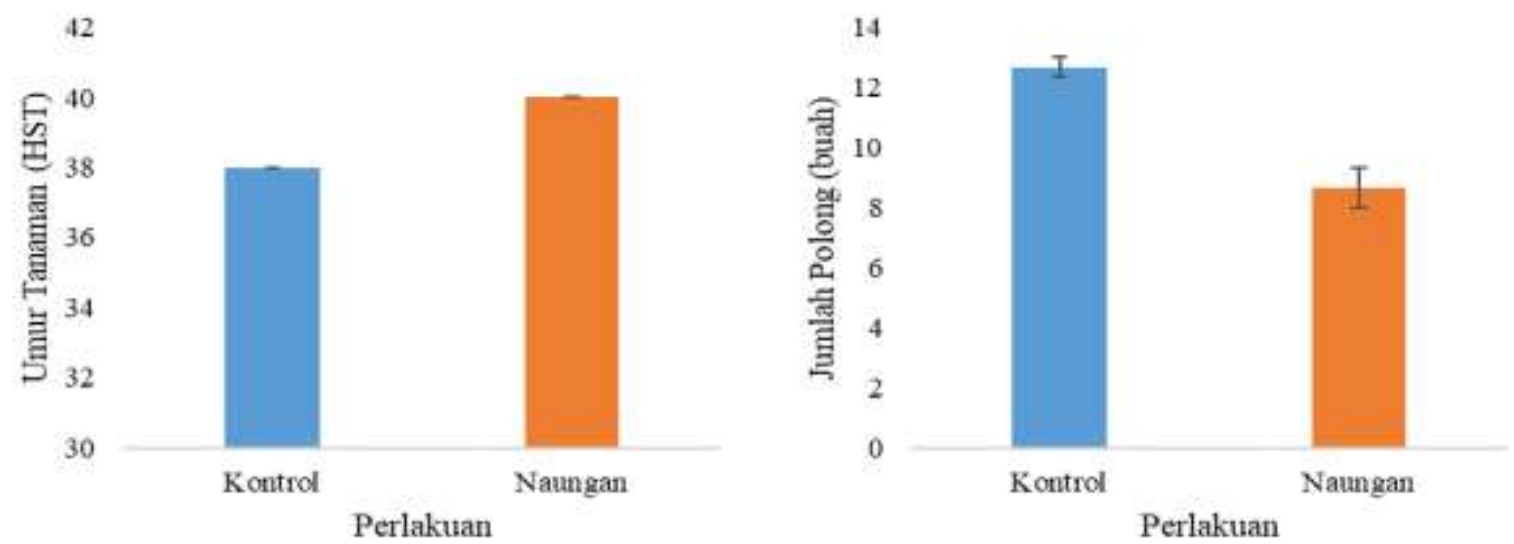

Gambar 4. Durasi kemunculan bunga pertama dan jumlah polong kacang tunggak setelah perlakuan naungan $40 \%$. Nilai angka adalah mean \pm SE $(n=3)$. 
Naungan membatasi ketersediaan fiksasi $\mathrm{CO}_{2}$ fotosintesis terkait dengan penurunan penyerapan cahaya (Cai, 2011). Terbatasnya fiksasi $\mathrm{CO}_{2}$ berdampak pada penurunan biomassa dan jumlah buah serta biomassa tanaman keseluruhan. Pada kacang kedelai (Glycine max) varietas Petek dan Jayawijaya menghasilkan jumlah polong lebih tinggi dalam kondisi tanpa naungan, sedangkan naungan 50\% menurunkan 50\% jumlah kacang polongnya (Darma dkk., 2012). Afandi dkk. (2013) melaporkan penelitiannya pada kedelai varietas Anjasmoro, Burangrang, Wilis dan Rinjani bahwa jumlah polong semakin sedikit seiring

\section{Berat Basah dan Berat Kering Tanaman}

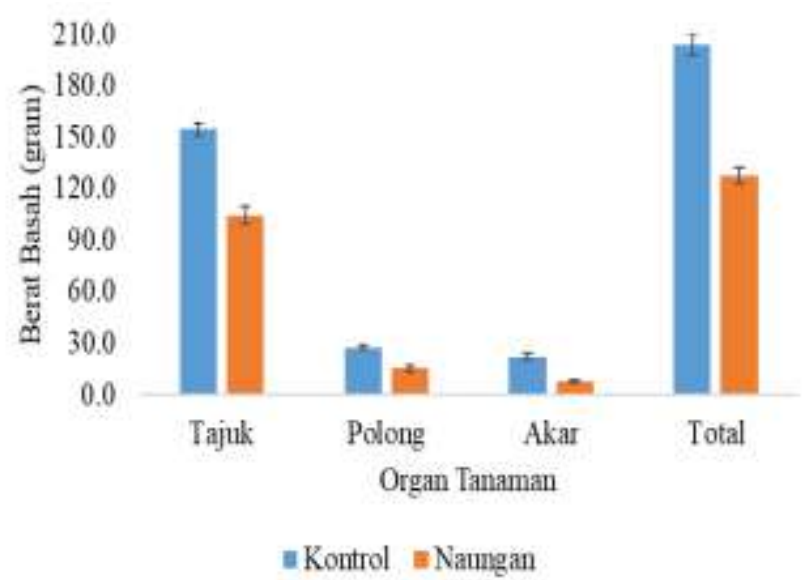

bertambahnya persentase naungan yang diberikan. Pada kacang tunggak, naungan memperpanjang durasi kemunculan bunga dan menurunkan jumlah polong. Nampaknya penurunan pertumbuhan kacang tunggak selama fase vegetatif menyebabkan penundaan inisiasi pembungaan dan munculnya bunga sehingga menurunkan jumlah dan biomassa polong. Hasil dari penelitian ini didukung oleh pernyataan Cai (2011) bahwa terhambatnya proses fisiologis pertumbuhan mengakibatkan tertundanya pembungaan, menurunkan biomassa dan jumlah bunga serta biomassa buah.

Gambar 5. Berat basah dan berat kering tanaman pada kondisi naungan $40 \%$. Nilai angka adalah mean \pm SE $(n=3)$.

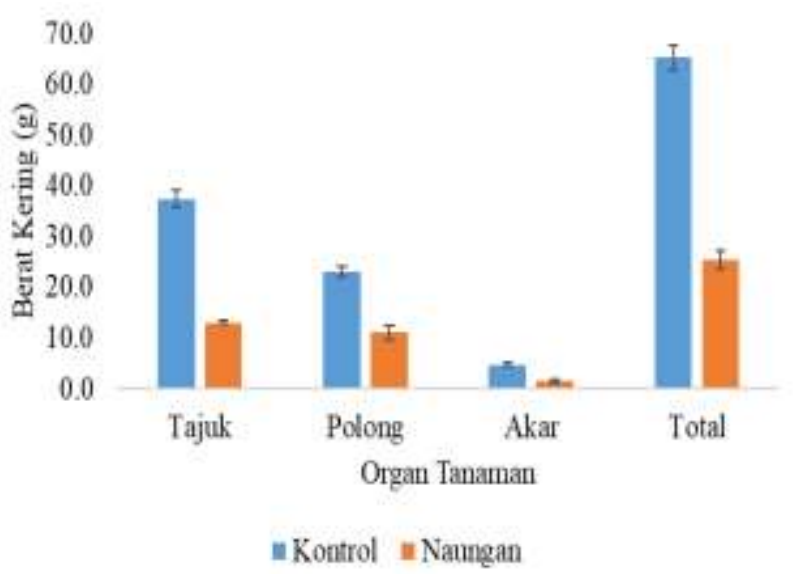

Terdapat perbedaaan yang signifikan $(\mathrm{P}<0,05)$ diantara rerata data berat basah dan berat kering tanaman. Naungan mengakibatkan penurunan secara nyata berat basah dan berat kering tajuk, akar, polong serta berat total tanaman (Gambar 5). Biomassa tanaman merupakan hasil dari penyerapan air, hara dan akumulasi fotosintat. Tanaman membutuhkan air, unsur hara dan energi cahaya agar aktivitas pertumbuhan dan perkembangan dapat berlangsung (Erwin, 2015). Gao et al. (2017), menyatakan bahwa naungan membatasi morfologi dan aktivitas fisiologis akar sehingga berdampak pada pertumbuhan tajuk di atas tanah. Naungan menyebabkan penurunan fungsi akar dalam penyerapan air, unsur hara dan aktivitas berbagai senyawa signaling. Penurunan fungsi akar akan membatasi pertumbuhan tajuk dan produktivitas tanaman. Penurunan biomassa kacang tunggak dalam kondisi naungan juga terjadi pada kedelai. Bestari dkk. (2018), melaporkan biomassa kedelai menurun seiring dengan peningkatan persentase naungan.

\section{KESIMPULAN}

Naungan sebesar $40 \%$ pada kacang tunggak meningkatkan daya perkecambahan benih. Naungan mendorong kacang tunggak mengembangkan strategi avoid atau menghindar dari nayngan dengan mempertahankan kandungan pigmen fotosintesis, meningkatkan tinggi dan jumlah daun serta menurunkan biomassa tanaman. Penurunan biomassa tanaman berdampak pada penundaan pembungaan, penurunan jumlah dan biomassa polong. 


\section{DAFTAR PUSTAKA}

Afandi, M., L. Mawarni, Syukri. 2013. Respon Pertumbuhan dan Produksi Empat Varietas Kedelai (Glycine max L.) terhadap Tingkat Naungan. Jurnal Agroteknologi. 1(2): 214 226.

Astuti, T., S. Darmanti. 2010. Produksi Bunga Rosella (Hibiscus sabdariffa L.) yang Diperlakukan dengan Naungan dan Volume Penyiraman Air yang Berbeda. Jurnal Pennelitian Sains dan Teknologi. 2(3):19-28.

Bestari, A. V., S. Darmanti, S. Parman. 2018. Respon Fisiologis Kedelai (Glycine max (L.) Merr.) Varietas Grobogan terhadap Tingkat Naungan yang Berbeda. Biospecies. 11(2): 53-62.

Cai, Z. Q. 2011. Shade delayed flowering and decreased photosynthesis, growth and yield of Sacha Inchi (Plukenetia volubilis) plants. Industrial Crops and Products, 34(1): 1235-1237.

Chairudin, Efendi, Sabaruddin. 2015. Dampak Naungan terhadap Perubahan Karakter Agronomi dan Morfo-Fisiologi Daun pada Tanaman Kedelai (Glycine max (L.) Merrill). Jurnal Floratek. 10: 26-35.

Darma, M., N. Soverda, Jasminarni. 2012. Pengaruh Naungan terhadap Nisbah Klorofil-A/B serta Hasil Dua Varietas Tanaman Kedelai (Glycine max (L.) Merrill). Bioplantae. 1(3): 161-170.

Erwin, S., Ramli, Adrianton. 2015. Pengaruh Berbagai Jarak Tanam pada Pertumbuhan dan Produksi Kubis (Brassica oleracea L.) di Dataran Menengah Desa Bobo Kecamatan Palolo Kabupaten Sigi. Jurnal Agrotekbis. 3(4): 491-497.

Gao, J., J. Shi, S. Dong, P. Liu, B. Zhao, J. Zhang. 2017. Grain yield and root characteristics of summer maize (Zea mays L.) under shade stress conditions. Journal of Agronomy and Crop Science. 203(6): 562573.

Gommers, C. M., E. J. Visser, K. R. St Onge, L. A. Voesenek, R. Pierik. 2013. Shade tolerance: when growing tall is not an option. Trends in plant science. 18(2): 6571.

Gong, W. Z, C. D. Jiang, Y. S. Wu, H. H. Chen, W. Y. Liu, W. Y. Yang. 2015. Tolerance vs Avoidance: Two Strategies of Soybean (Glycine max) Seedlings in Response to Shade in Intercropping. Photosynthetica. 53(2): 259-268.

Huang, D., L. Wu, J. R. Chen, \& L. Dong. 2011. Morphological plasticity, photosynthesis and chlorophyll fluorescence of Athyrium pachyphlebium at different shade levels. Photosynthetica. 49(4): 611-618.

Idris, A., A. C. Linatoc, A. M. Aliyu, S. M. Muhammad, M. F. Bin Abu Bakar. 2018. Effect of Light on the Photosynthesis, Pigment Content and Stomatal Density of Sun and Leaves of Vernonia amygdalina. International Journal of Engineering and Technology. 7(4.30): 209-212.

Idris, A., A. C. Linatoc, M. F. B. A Bakar, Z. I. Takai. 2019. Effect of Light Intensity on the Gas Exchange Characteristics and Total Pigment Content of Psidium guajava. IOP Conference Series: Earth and Environtmental Science. 269: 012020.

Ismayanti, M. dan Harijono. 2015. Formulasi MPASI Berbasis Tepung Kecambah Kacang Tunggak dan Tepung Jagung dengan Metode Linear Programming. Jurnal Pangan dan Agroindustri. 3(3): 996-1005.

Kittas, C., N. Rigakis, N. Katsoulas, T. Bartzanas. 2009. Influence of Shading Screens on Microclimate, Growth and Productivity of Tomato. Acta Horticulturae. 807: 97-102.

Latue, P. Ch., H. L. Rampe, M. Rumondor. 2019. Uji Pematahan Dormansi Menggunakan Asam Sulfat Berdasarkan Viabilitas dan Vigor Benih Pala (Myristica fragrans Houtt.). Jurnal Ilmiah Sains. 19(1): 13-21.

Masabni, J., Y. Sun, G. Niu. P. D. Valle. 2016. Shade Effect on Growth and Productivity of Tomato and Chili Pepper. HortTechnology. 26: 344-350. 
Prasundari, I. R., E. Widaryanto, Sitawati. 2018.

Studi Toleransi Dua Tipe Tanaman Petunia (Petunia $x$ hybrida) terhadap Naungan. Jurnal Produksi Tanaman. 6(4): 569-578.

Roig-Villanova, I., \& J. F. Martínez-García. 2016. Plant responses to vegetation proximity: a whole life avoiding shade. Frontiers in plant science. 7: 236.

Semchenko, M., M. Lepik, L. Götzenberger, \& K. Zobel. 2012. Positive effect of shade on plant growth: amelioration of stress or active regulation of growth rate?. Journal of ecology. 100(2): 459-466.

Silva, F. M., D. M. Dresch, Z. V. Pereira, R. M. Mussury, S. D. Scalon. 2015. Effect of Shade on Emergence, Initian Growth, and Seedling Quality in Physocalymma scaberrimum. Brazilian Journal of Botany. 39: 185-191.

Tabin, T., K. Shrivastava. 2014. Factors Affecting Seed Germination and Esrablishment of Critically Endangered Aquilaria malaccensis (Thymelaeaceae). Asian Journal of Plant Science and Research. 4(6): 42-46.

Wartenberg, A. C., W. J. Blaser. J. M. Roshetko, M. V. Noordwijk, J. Six. 2019. Soil Fertility and Theobroma cacao Growth and Productivity Under Commonly Intercropped Shade-tree Species in Sulawesi, Indonesia. Plant and Soil.

Wellburn, A. R. 1994. The Spectral Determination of Chlorophylls $a$ and $b$, As Well As Total Carotenoids, Using Various Solvents with Spectrophotometers of Different Resolution. Journal Plant Physiology. 144(3): 307-313.

Yusuf, H. 2009. Pengaruh Naungan dan Tekstur Tanah terhadap Pertumbuhan dan Produksi Bawang Sabrang (Eleutherine americana MERR.). Skripsi. Fakultas Pertanian. Universitas Sumatera Utara. 